\title{
Rethinking disability in Amartya Sen's approach: ICT and equality of opportunity
}

\author{
Mario Toboso \\ Institute of Philosophy, Centre for Humanities and Social Sciences (CCHS) - Spanish \\ National Research Council (CSIC) \\ <mario.toboso@csic.es>
}

Ethics and Information Technology, Volume 13, Number 2, 107-118.

\begin{abstract}
This article presents an analysis of the concept of disability in Amartya Sen's capabilities and functionings approach in the context of Information and Communication Technologies (ICT). Following a critical review of the concept of disability-from its traditional interpretation as an essentially medical concept to its later interpretation as a socially constructed category-we will introduce the concept of functional diversity. The importance of human diversity in the capabilities and functionings approach calls for incorporating this concept into the analysis of wellbeing and quality of life in persons with disability-aspects in which ICT currently plays a major role. When one contemplates these technologies, it becomes clear that factors such as accessibility, design for all, and user participation in development and implementation processes are key strategies in promoting equal rights and equal opportunity for persons with disability in the different environments of the information society.
\end{abstract}

Key words: accessibility, Amartya Sen, Convention on the Rights of Persons with Disabilities, design for all, disability, functional diversity, ICT, medical model, social model

\section{Disability: from medical essentialism to social constructionism}

From ancient times to the present day, there have been persistent, serious contradictions in the way persons with disability are treated in society as a result of conflicting concepts of disability (Aguado 1995; Stiker 1999; Üstün et al. 2001). In essence, we will present the two paradigms or basic models (Palacios 2008; Cabrera 2009) of how persons with disability are treated in society that coexist, to a greater or lesser extent, in the current ethical and regulatory climate.

The so-called 'medical/rehabilitation model' of disability (or, simply, 'medical model') originated practically at the beginning of the modern world. It was consolidated, however-especially in terms of legislation - at the beginning of the twentieth century following the World War I, which left thousands of people wounded or maimed for life with limitations in their physical, sensory or intellectual functions. To differentiate them from people whose functional limitation was rooted in other causes such as work accidents (Stiker 1999), they were specifically referred to as the 'war-maimed'.

Society's conviction that the war-maimed should be compensated for the harm they had suffered was established in the realm of Law through measures guaranteeing them a group of social services: disability pensions, rehabilitation benefits and work quotas. 
These were subsequently expanded during the 1970s to cover any persons with disability, regardless of its origin (war or work accident). It became society's basic objective, therefore, to rehabilitate people with disabilities (De Asís et al. 2007) and, to that end, society articulated social services such as those mentioned above as well as special education programs, protected employment and institutionalized assistance services.

The medical model has two basic features: first, the alleged causes of the disability are medical in nature. A medical orientation means that disability is spoken of in terms of 'disease' in this model. Thus, persons with disability become objects of medical care, and their reality is examined and explained through a 'medicalized' and 'medicalizing' prism.

Second, persons with disability do have something to contribute to society, but only insofar as they have been rehabilitated or normalized and have been integrated as much as possible with people of normal abilities. Focusing the attention on what persons with disability are unable to do, leads to an underestimation of their aptitudes and, in turn, to a paternalistic and charitable attitude toward their limitations. As a result, society treats them as if they were of less value than people without disability and, under the medical model, it became a routine practice to create overprotective spaces-assistance institutions of every kind-for these persons (Finkelstein 1980; Brisenden 1986; Barnes and Mercer 1996).

In essence, the so-called 'social model' of disability arose from a rejection of these features of the medical model. It originated in the late 1960s and early 1970s in the United States where a long tradition of political campaigning for the civil rights of certain marginalized groups gave impetus to a growing protest movement on behalf of persons with disability. Some of its demands were to gain civil rights, demedicalization, and de-institutionalization (De Asís et al. 2007) to answer the intervention strategies of the medical model of that era.

Thus, the so-called 'independent living movement', which may be considered the immediate forerunner of the social model, opposed the professional dominance and government-provided social services that were part of the medical model and demanded opportunities for persons with disability to develop their own free-market services. Advocacy for self-managed rehabilitation services based on the individual's own objectives, delivery methods, and program management began with the independent living movement. The individual's autonomy and ability to choose and be in control have been emphasized, and management of personal care has been left in the hands of the persons with disability themselves-in contrast to the prevailing paternalistic practices (DeJong 1979; Scotch 1985; Shapiro 1994; Charlton 1998).

The basic features of the social model are as follows: first, the root causes of disability are viewed as social rather than medical in nature. This interpretation is a reversal of major importance, for disability is no longer assumed to originate with the individual's limitations, but rather with society's limitations in taking the specific, functional requirements of those individuals into consideration (Swain et al. 2004; De Asís et al. 2007). This does not mean, however, that the personal aspects of disability-prioritized 
in the medical model-are denied; rather, they are framed in a more balanced perspective that places them in the social context.

Second, persons with disability are viewed as being just as capable as anyone else of making contributions to society. The social model maintains, for the first time, that what contribution to society persons with disability can make is closely related to their difference being fully accepted (Palacios and Romañach 2006) — as opposed to it being hidden and them being integrated with others, as was seen in the medical model.

In the social model, disability is understood as a problematic interaction between an individual who has a specific, functional requirement and an environment that is designed without taking that requirement into consideration (Hunt 1966; Swain et al. 2004). While the medical model's principal objective was to normalize persons with disability, the social model aims to normalize society so that it considers, plans, and designs for the needs of all people and becomes as inclusive as possible (Barnes and Mercer 1996; Barton 1996; Hales 1996; Oliver 1996).

Thus, the social model operates on the premise that disability is a social construct - the result of society's failure to keep persons with disability in mind when designing and constructing venues for activity and participation. In this connection, the social model defends the autonomy and freedom of these persons to make choices regarding all aspects of their own life and, therefore, focuses on eliminating any barriers to that so that equal opportunity is truly provided (Abberley 1987). Disability is understood, then, as the product of a 'disabling' society — not the result of an individual's pathology. Being 'disabled' by society is directly related to discrimination (Barnes 1991) and also to prejudice (Shakespeare 1994), both of which restrict opportunities for participation for persons with disability (Shakespeare and Watson 1996).

The social model is a departure from addressing disability in terms of medical conditions, as is typical in the medical model. Still, it does not mean concealing an undeniable medical reality, which many persons with disability have, but rather consigning strictly healthcare-related issues to the medical realm and not mixing them with social issues stemming from the disability. Neither physicians nor the medical model must dictate how persons with disability live-they themselves must be able to choose, freely and autonomously, the way they wish to live. This requires that, in the field of disability, there be a strict separation between the social and the healthcare realms (Palacios and Romañach 2006, p. 131). Medicine, on the one hand, must follow its course and recommend solutions pertinent to medical issues; society, on the other hand, must promote equal opportunity in every area to prevent the discrimination that persons with disability have traditionally endured.

\section{Toward a new model based on diversity}

In Spain, authors Palacios and Romañach (2006) are currently proposing that a new perspective is needed-a new model of disability for society to consider that is based on a definitive acceptance of human diversity and rises above the ability/disability conceptual dichotomy. This new approach is anchored in a vision of human rights and 
views research in the field of bioethics as a basic tool for achieving a full measure of dignity for persons with disability (DPI-Europe 2000a; Wolbring 2003; Palacios et al. 2009). The debate over and impetus for this new perspective is taking place in the context of the independent living movement in Spain.

This proposed new approach, which its authors call the 'diversity model' (Palacios and Romañach 2006), is presented as an evolution of the social model. In the social model, the approach to treatment of persons with disability is based on securing their full participation through equal opportunity and the elimination of discrimination and, similarly, on the need for them to be accepted without having to resort to concealing the supposed difference that leaves them outside the parameters of normality (Palacios and Romañach 2006, p. 207; Cadwallader 2007).

Whereas, in the social model, the basic principles are a person's ability and opportunity to make a contribution in society, the basic principles of the diversity model are diversity and human dignity. Therefore, it goes beyond the core theory of ability which, under the former models, imposed a vain attempt to 'be like the other person'- to aspire to a normality that is statistically incompatible, in many cases, with the intrinsic diversity of human beings.

To bring about this shift, it is crucial to overthrow the old concept of ability and look for a new concept in which persons with disability can find an identity that is not perceived as negative. Through the diversity model, the proposal of Spain's independent living movement embraces the concept of 'functional diversity' as a much more meaningful, up-to-date, and positive concept than 'disability' with its negative connotations (Romañach and Lobato 2005). This designation is accompanied by the proposal of a new, non-negative vision that makes reference to persons who perform some of their functions in a way that is different from the average person. In this new approach, then, the point of departure is a basic reality: that, in terms of functioning-physical, mental, and sensory-humans being are diverse, and all societies should view this diversity as a source of enrichment (Palacios and Romañach 2006).

\section{Functionings, capabilities and diversity in Amartya Sen's approach}

Attention to human diversity-both the individual's characteristics and external circumstances-constitutes an important aspect of Amartya Sen's capabilities and functionings approach. This approach arises in the context of human development as a conceptual framework for analyzing people's well-being and quality of life (Sen 1985). It maintains that, since an increase in gross national product is not the bottom line of human development, it is not appropriate to evaluate well-being and quality of life in terms of disposable income. Rather, development has to do with what people are actually able to do or be - their so-called 'functionings' - and with their 'capabilities', which are understood as the opportunities they have to choose and be able to live in any given way.

At its most rudimentary level, the concept behind this approach centers on functionings. These represent what a person manages to achieve or become in life. Some functionings 
may be very basic - being properly nourished or having good health, for example — and, for obvious reasons, these may have great weight assigned to them. Others such as achieving self-esteem and being well integrated socially may be more complex but equally valued. However, people can differ widely as to how much weight they place on functionings (Sen 1993, p. 31).

Functionings allow well-being to be understood in an innovative way: instead of being defined in terms of either the utility or the quantity of available resources, well-being is now an assessment of people's living conditions as defined by their functionings. These are the truths of a person's life-the factors that determine how that person lives (Sen 1987, pp. 1-38). According to Sen (1999, p. 53), life may be thought of as a set of interrelated functionings consisting of states and actions.

Capability, in turn, reflects the possible combinations of functionings a person may achieve, from among which the person may chose an array of them. Within the concept of capability, three levels of analysis should be distinguished (Cejudo 2007): one must proceed from the usual way of understanding 'capability' - as the capacity to succeed at achieving something - to the idea of 'capability to function' and then, finally, to the idea of an 'capability set', which comprises all the functionings that are within the realm of possibility for an individual.

Formally, capability to function adds to the idea of functioning the real possibility of choosing to function that way or not - of having the appropriate resources and whatever is required to capitalize on it. Thus, for example, a person with disability will require more resources and/or a more favorable social environment to be able to travel (a functioning). To put it another way, an equal amount of available resources does not automatically translate to an equal capability to function, for each case has its individual features and social circumstances-a basic element of diversity that cannot be discounted (Cejudo 2007, p. 15).

The same income may result in great inequality in terms of our capability to achieve the functionings that are important to us. Returning to the example, if a person with disability and a person without disability both have exactly the same income, it is highly unlikely that the person with disability will be able to function just like the person without disability. This is how it is that equality with respect to one variable (income, for example) can give rise to great inequality in terms of another variable (capability to function or well-being, for example). This matter of what 'evaluative realm' we choose-that is, what variables we choose to focus on-is crucial in analyzing inequality. ${ }^{1}$

\footnotetext{
${ }^{1}$ Sen (1999, pp. 29-33) explains that, if everyone were exactly the same, equality in any given sphere (income, for example) would be consistent with equality in other spheres (health, wellbeing, or happiness, for example). One upshot of human diversity is that equality in a particular sphere usually goes hand in hand with inequality in various other spheres. Inequality in some spheres is justified by the fact that there is equality in some other sphere that, from an ethical point of view, is considered more basic. The equality considered to be 'more basic' would be put forward as a logical rationalization for the inequalities present in the other spheres. See also, Sen (1979, pp. 202, 215, 219).
} 
Sen points out that, since we are so profoundly diverse, equality in one realm often leads to inequalities in other realms. Thus, the force of the question 'equality of what?' stems largely from the empirical fact of our lack of similarity-in physical and mental abilities and inabilities, susceptibility during epidemics, age, gender, and other factorsas well as the social and economic underpinnings of our lives and our freedom (Sen 1979, p. 215).

Sen's capability theory revolves around a primary concern about freedom. His reply to the fundamental question 'equality of what?' is equality of personal freedomunderstood as the capability to achieve the functionings one considers necessary to have a good life-over equality of income or wealth.

As an approach to evaluating human well-being and equality of personal freedom, the capability theory assesses the particular position of a person within a social order from two different perspectives: 1) well-being, defined as the valued achievements and functionings attained, and 2) freedom, defined as the real opportunities a person has to attain well-being. Although it is not necessary that these two perspectives coincide or be congruent with each other, the first would be incomplete if we were to ignore at least a theoretical consideration of the second-for freedom, defined in this way, is indispensable to the achievement of well-being and to the attainment of any meaningful quality of life. ${ }^{2}$

Freedom, defined as real opportunity to make choices, is of unequivocal importance to people's quality of life and well-being. The power to act freely and make choices directly promotes well-being - and not only because more freedom may mean there are more choices available. If the power to choose is deemed an important facet of life, and if a distinction is made between simply 'doing $X$ ' and 'choosing $X$ and doing it', then it must be understood that well-being is influenced by the freedom reflected on the range of possibilities for the functionings set. ${ }^{3}$

The essence of Sen's proposal lies in his argument that a theory of justice as equity must incorporate real freedoms that all kinds of people, possibly with quite different

\footnotetext{
${ }^{2}$ If we compare, for example, the situation of someone who is starving with that of someone who is fasting, from the standpoint of functionings (perspective 1), there is no difference-both persons are in the same state of food deprivation. When we compare these two states from the standpoint of freedom (perspective 2), however, then the fundamental difference surfaces: the first person has no choice but to be starving while the second person has freely chosen to be fasting, and the obvious result is that the first person is at a disadvantage with respect to the second person.

${ }^{3}$ In the same example, as a functioning, 'fasting' does not mean simply 'being hungry' but rather 'choosing to be hungry and doing it' when one has other possible alternatives. Likewise, choosing to live a lifestyle (perspective 2) is not exactly the same as simply living that lifestyle (perspective 1) without considering how one arrived at that lifestyle; well-being hinges on how that came to be the person's lifestyle (Sen 1999, p. 65). The difference between these two perspectives is clearly exemplified if one contemplates, on the one hand, the possible measure of well-being a person with disability can achieve through the intervention strategies of the medical model and, on the other hand, the personal autonomy and freedom of choice that are promoted through the emancipating practices of the independent living movement that are incorporated in the social model.
} 
objectives, can enjoy. This is why the true degree of freedom people have to consider various possible lifestyles for themselves must be taken into account. In applying the capability approach, the point of interest is the evaluation of people's advantages or disadvantages with regard to their capability to achieve valuable functionings that they believe are elements essential to their lifestyle. ${ }^{4}$

As a central issue, we must distinguish between freedom and achievement - or the concrete functioning attained. Capability is a reflection of the freedom to choose between lifestyle alternatives - that is, between different combinations of functionings. In using the capability approach, it is crucial to consider how each person transforms the resources at hand into concrete achievements, for everyone's circumstances are different (Álvarez 2001). Capability means freedom as long as resources are simply a means to exercise that freedom-not when there are differences between people in terms of what concrete freedoms they are able to attain with those resources. As we have shown, those disparities between individuals must be taken into account.

\section{ICT, capability approach and functional diversity}

Information and Communications Technologies (ICT) comprise the wide array of present-day technological elements and resources that are becoming more and more a part of people's everyday lives. Routine contact with such technologies has transformed them into what Vacas (2007) calls 'technologies for daily living' that become ensconced, little by little, in the lives of millions of non-professional users. These include mobile phones, personal computers, PDAs, the whole array of Internet options_-websites, blogs, and chats, for example_digital cameras, MP3 and MP4 players, DVD players and burners, and GPS navigators, among others.

ICT are usually viewed as simple tools for accessing information and for communicating. This conceptualization of technologies as mere instruments (Feenberg 1991, p. 5; Tiles and Oberdiek 1995) is not sufficient, however, to understand the profound change that ICT have brought about in society (Echeverría 2008, p. 174) and has led to a proposal that technologies, in general, be looked upon as human action systems: A technical achievement is a human action system that is intentionally aimed at transforming concrete objects to obtain a valued result in an efficient manner. (Quintanilla 1989, p. 34). In the case of ICT, this proposal implies paying attention to not only the new tools that come out but also the way these tools modify human actions and, in particular, what new actions they make possible.

In addition to transforming communications and access to information, ICT have profoundly altered a significant portion of human capacities for action. A human action

\footnotetext{
${ }^{4}$ There is room for disagreement, obviously, as to what functionings are valuable. Instead of viewing this as a disadvantage, however, Sen believes that room for disagreement is something to be appreciated. This is because the capability approach does not attempt to provide a decisive, computer-programmable method; rather, it tries to reflect upon what functionings are part of the concept of 'a good life' in our culture and others and, in addition, to investigate what real freedom various groups of people have to achieve these valuable functionings (Putnam 2004).
} 
can now have an impact in locations quite a distance away, geographically, and affect millions of people and devices both simultaneously and in reorded form (Echeverría 2006). This great technological transformation makes a new form of social organization possible: the information society or network society (Castells 1996). Thus, it is not only about acquiring information or knowledge but also about developing new technological skills so that one can become integrated and participate actively in this new modality of society.

As elements that alter human capacities and make new actions possible, ICT transform a person's capability set (Echeverría 2008, p. 175), which Amartya Sen defines as the set of all possible functionings a person can achieve. In connection with these technologies, functionings are defined by what the person is doing, in effect, when using them - that is, by the actions the person is performing by means of the ICT, which depends on the technologies available and the person's knowledge and ability to use them.

ICT give rise to new capacities for action, but the vast array of new technological devices results in a variety of choosing and rejecting behaviors. Analysis of these behaviors must take into account the various socio-cultural processes that come into play with different ICT user groups and the significance ICT has for them-factors that should also be considered in forming a reliable diagnosis and prognosis as to whether it is possible to create an information society that is inclusive of everyone (Winocur 2007). All of that relates to the idea of social 'appropriation' of these technologies, which is highlighted when they are utilized in developing actions that are meaningful to people (Hoyos 2002; Echeverría 2008).

Generally speaking, it would be necessary to study whether different human groups are appropriating ICT for themselves and whether, besides possessing them and being familiar with them, they are also using them effectively in their daily activities. According to Sen's theory, this appropriation of technologies is evident in the action systems (functionings) that are carried out with them. If someone is performing effectively with ICT, that person can become integrated into the information society and be active in it. Otherwise, this person is at risk of being excluded (Echeverría 2008, p. 176).

Many persons with disability utilize technological resources-often those associated with accomplishing everyday functionings-in preserving their own quality of life and their opportunities for participating in society. This may be the case of a tetraplegic person who gets around in a motorized wheelchair; a blind person who uses a localization and orientation device to guide his or her movements when away from home; or the specific resources and interfaces they both may utilize routinely when on the computer.

The capability set of these persons incorporates these technological resources as elements inherent to their functionings, for it is not a matter of deciding whether or not to use them-these resources are already part of the very nature of a particular functioning and the opportunity to achieve it. There is a clear example of technologies appropriation here, insofar as those technologies make it possible to achieve 
functionings in their capability set that are obviously important and meaningful to these persons. In other words, their capability set is configured as a functionings space based on the appropriation of technologies that contribute to making them possible.

Thus, we come to an issue that is central to our presentation: we believe that consideration of human diversity—so important in Amartya Sen's proposal—should involve not only a description of each person's individual characteristics and environmental features but also the details of how they achieve their functionings. As we have stated above, many persons with disability carry out particular daily functionings with the aid of technological devices while persons without disability generally do not require such assistance to do them. It is important to note, however, that while the functioning achieved in each case may be the same, it is achieved in a different way.

In this regard, we believe that the concept of 'functional diversity' (introduced in the diversity model) may be interpreted as 'diversity on functionings', describing the reality of persons who have the potential to access the same functionings as other people but in a different way-often through the use of technical components and technological resources. This perspective suggests that, in an evaluation of well-being and quality of life, the capability set that is taken into account should include the whole range of possibilities for the functionings space-in keeping with the fact that different members of the society have different ways of accessing them. In other words, the functioning 'go outside the house', for example, should take into consideration the various ways of doing that and not be limited to the legitimate and most common ways used by the majority.

If the proposal is approached in this way, consideration of a capability set that incorporates these diverse ways of achieving possible functionings should go hand in hand with consideration of an agency environment that has the capacity to respect that diversity and does not limit this capability set for persons with disability because there are limiting factors that may invalidate functioning alternatives for these persons. Although significant progress has been made toward recognizing that persons with disability deserve equal rights and opportunities (UN 2006, 2008), they still frequently encounter obstacles to living a full life and participating in activities on an equal footing with people who have no disability.

A milestone in this progress was marked on December 13, 2006: the UN General Assembly adopted the Convention on the Rights of Persons with Disabilities (hereinafter, 'the Convention'), and the disability phenomenon became, unequivocally, a human rights issue. It was an historic advancement for the more than 650 million persons with disability around the world-that $10 \%$ of humanity that has been most forgotten and discriminated against throughout history in almost every human society. This persistent discrimination is acknowledged in the text of section $(\mathrm{k})$ of the Convention's Preamble (UN 2006), which points out that “[...] persons with disabilities continue to face barriers in their participation as equal members of society and violations of their human rights in all parts of the world." 
The Convention is the fruit of a long process formally initiated in 2001 in response to a progressive change taking place in the realm of international law-a shift from instruments that viewed disability from the medical/rehabilitation model perspective toward those that, like the Convention, share a vision closer to the social model and a vision of human rights, above all. The Convention represents, then, the latest manifestation of a worldwide trend toward making persons with disability more visible in the sphere of both values and law. ${ }^{5}$

\section{Accessibility and equal opportunity: user participation in technological design}

Over the last twenty years, social studies of science and technology have proven very fruitful, yielding a philosophical perspective that enables a wide range of values to be taken into account: besides epistemic and technical values, a comprehensive system of financial, business, political, and legal values, including the social and ethical values associated with scientific-technological practice (Laudan 1984; Proctor 1991; Pickering 1995; Rescher 1999; Echeverría 2002). These values open the way to addressing important social issues connected with them, as is the case with disability, and scrutinizing the scientific and technological practices that are oriented to and have their context within such issues (Seelman 2001).

Various authors in the field of philosophy of technology maintain that, to achieve technological development that addresses the needs of society, the values and interests involved must be expanded (Lopez Cerezo el al. 1998; Schot 2001; Feenberg 2002) because the purely financial interest is usually the primary one present. This expansion requires that more of the society's actors participate. Traditionally, the only ones involved in technology management have been the political and financial authorities and the experts associated with public or private interests (European Commission 1994, p. 10; Hamelink 2000, Seelman 2001). The model of participation thus configured is very far from one that can meet the current requirements for resolving technological problems (Stirling et al. 1999, Winner 2007). To direct the shift toward technology that is more respectful of society's needs, more of society's actors must be encouraged to participate so that there is a broader representation of values and interests in the process. $^{6}$

User participation in technological development processes contributes to a better representation of the social factors involved. Participating in these processes is not limited to interceding in technical decisions, however, for development of the technology is not conditioned on those decisions alone (Martín Gordillo 2005). All decisions involve values-related dilemmas that call for citizen participation-users,

\footnotetext{
${ }^{5}$ The Convention is the twenty-first century's first international treaty. In its 50 Articles, it assembles the principles that govern its application; the rights designed to protect and promote freedom, equality, and dignity for persons with disability, and the obligations of countries that adopt it, under which States are required to work toward establishing non-discrimination measures and policies such as adapting their legal codes to the Convention content.

${ }^{6}$ According to the 2001 UNESCO report $(2001$, p. 3) on ethics in the information society: "Values affect the shape of technologies and thus, even when describing technical features of systems and devices, one needs to pay attention to values."
} 
consumers, those responsible for the technological products, those affected by them, and so forth. ${ }^{7}$

It has been widely debated whether ICT represent an opportunity or, quite the opposite, a new cause of exclusion for persons with disability (Sheldon 2001, 2004; Dobransky and Hargittai 2006). There is consensus that, if these technologies have the greatest possible 'accessibility' and if they are compatible with the technical support devices each person owns, then ICT will bring persons with disability innumerable benefits and new opportunities for education, employment, leisure, and participation in society (G3ict 2007). In this regard, section (v) of the Convention's Preamble (UN 2006) emphasizes "the importance of accessibility to the physical, social, economic and cultural environment, to health and education and to information and communication, in enabling persons with disabilities to fully enjoy all human rights and fundamental freedoms". Accessibility is one of the "General Principles" (Article 3) guiding the Convention, and its entire Article 9 is devoted to this subject.

In a general way, accessibility may be understood as the opportunity people have to access goods, products, and services, taking into consideration their specific needs. Accessibility has to do primarily with overcoming the barriers that may keep people with physical, sensory, intellectual, behavioral, and other differences from enjoying them. On the other hand, this opportunity for access also refers to the array of material and/or human means that enable people to enjoy such goods, products, and services and the environment in which they occur as autonomously as possible. ${ }^{8}$

For many years, society looked upon the fact that persons with disability were not able to access buildings and many other environments, goods and services of daily life as a matter of misfortune-not a matter of concern to society. This traditional and

\footnotetext{
${ }^{7}$ In this sense, a major effort was made to address this issue at the World Conference on Science, convened by UNESCO and the International Council for Science (ICSU) and held in Budapest in June and July of 1999. The event closed with approval of the Declaration on Science and the Use of Scientific Knowledge. The objective of both the Conference and the Declaration was to articulate and reach a consensus on a new social contract for science. Of special importance to the subject we are addressing in this section is Article 42 of this Declaration, which states the need to resolve the difficulties that obstacles still present for the so-called "disadvantaged groups" and that hinder their full and effective participation in science and technology - and persons with disability are expressly included in these groups. In the same regard, the following Articles of the Declaration are also relevant: Article 25 "that there are barriers which have precluded the full participation of other groups, of both sexes, including disabled people [...]", and Article 34 "Special attention still needs to be given to marginalized groups. It is more than ever necessary to develop and expand science literacy in all cultures and all sectors of society $[\ldots . .$. "

${ }^{8}$ For a person who uses a wheelchair, for example, an 'accessible' elevator must have a door of sufficient width and buttons placed at an appropriate height so this person can use them; for a person who is visually impaired, the same elevator should have its buttons labeled in Braille and an auditory indicator for the different floors; for a person with intellectual disability, it should incorporate easy-to-understand, adapted pictograms; and, for a person with a hearing deficit, there would have to be illuminated signage, information in sign language, and so forth. If all of these elements are present, then it could be said that this elevator is accessible to the group of users that were taken into consideration.
} 
discriminatory view did not consider that the inappropriate design of environments, services and products was causing a violation of the principle of equal rights and opportunities (European Commission 2001). In addressing discrimination on the basis of disability, the new proposals, derived from the social model, call for society to adapt its goods and services to the possible special needs of its people-not the other way around.

Although it is true that, traditionally, efforts to combat the lack of access have been focused on eliminating physical and architectural barriers, a broader vision of accessibility requirements is currently being consolidated. In a society immersed in the massive use of technology, there are not only physical barriers but also barriers to information and communication. In the realm of ICT, a tradition of 'standard' design for users-anchored in some hypothetical parameters of 'normality'-still prevails in product and services development. Not even Internet technologies are free of barriers. When, in theory, there should be improved access to information and services for all citizens, persons with disability are repeatedly excluded from the content of web pages that are not accessible to the specific interfaces they utilize (Goggin and Newell 2003, p. 119; W3C 2005).

\section{Integrating functional diversity through design for all}

Achieving accessibility is supported by an ideological principle and an active strategy, which brings us to the idea of "Design for All" (or "universal design"). Historically, the movement initiated in the United States, which advocated for equal opportunity for persons with disability to exercise their civil rights, began to become aware that design was a key element on the road to this equality. In the 1970s, the emphasis began to shift from particular design solutions conceived as special adaptations aimed at certain persons toward the more general idea of normalization and society's adaptation to people through design. The terminology employed gradually shifted from the initial "design without barriers" toward "accessible design," finally becoming "universal design" or "Design for All.",

Design for all or universal design appears in the text (UN 2006) of the Convention (Article 2), as well, where it is defined as "the design of products, environments, programmes and services to be usable by all people, to the greatest extent possible, without the need for adaptation or specialized design. "Universal design" shall not exclude assistive devices for particular groups of persons with disabilities where this is needed."

The foregoing definition reflects one of the traditional debates in disability studies, which refers to the relationship between universal design and assistive technologies in terms of promoting opportunity for access to and use of goods, products, services,

\footnotetext{
${ }^{9}$ Interest in the universal design concept expanded in the 1990s-above all, in the area of industrial design (Mace et al. 1991). Architect Ron Mace asked a group of designers and attorneys to develop a set of principles, known as the "seven principles of universal design," to provide designers with a guide to design features that facilitate integration of the needs of as many users as possible (Center for Universal Design 1997).
} 
environments, etc., by persons with disability. Both universal design and assistive technologies have advantages and disadvantages in addressing the special needs of these persons. Universal design constitutes a means by which persons with disability have demanded their inclusion and participation in society from the responsible politicians and product designers and developers. It is noteworthy that universal design, as an idea and in theory, at least, offers simplicity and ease when it comes to new suppliers grasping it. It is an approach that proposes to reorient the traditional thinking about design, as a key factor that is influential in the realm of people's functional characteristics. $^{10}$

This is a challenge and a significant limitation for universal design, which is concerned, in particular, with the broad diversity of functional characteristics inherent in every human circumstance and condition. In this regard, it is necessary to point out that, on occasion, different disability profiles come into conflict in terms of their specific design requirements. Thus, for example, a wheelchair user may think that wider spaces are more convenient whereas a blind person may feel less comfortable in those spaces because the frame of reference there is not so easy to span. Each disability profile has specific requirements that, in practice, should be met in such a way as not to conflict with other profiles. The best option for achieving this objective would probably involve an optimal combination of universal design and assistive technologies, where necessary and if an additional utility for the particular user must be provided through them. In any case, advancements should continue in both directions - the debate between universal design and assistive technologies being considered a fruitful relationship between complementary, non-excluding options in the sphere of promoting personal autonomy and social participation for persons with special functional requirements (Aslaksen et al. 1997, Mueller 1998, Vanderheiden 1998).

Design for all is a paradigm developed and promoted through research and practices in the realms of architecture, transportation, industrial design and, more recently, information and communications technologies (Aslaksen et al. 1997). It encompasses the design, development and marketing of products, services and environments that are accessible to and usable by the greatest possible variety of users. In essence, design for all focuses on finding solutions in the design phase itself so that, without the need of special adaptations, as many people as possible, regardless of their age and functional abilities (physical, mental, and sensory) can access products and services, and thereby participate actively in society. ${ }^{11}$

\footnotetext{
${ }^{10}$ With a view to taking into consideration the very diverse characteristics and expectations of different groups of people, the designing of products and services should be as participatory as possible so that people and groups with very different and perhaps contradictory perspectives may have an influence on all facets of the development of these products and services as well as the situations in which they are used (Goggin and Newell 2003, p. 150; Clarkson et al. 2003).

${ }^{11}$ In this regard, the Stockholm Declaration (2004) of the European Institute for Design and Disability (EIDD) states: "Design for All aims to enable all people to have equal opportunities to participate in every aspect of society. To achieve this, the built environment, everyday objects, services, culture and information, in short, everything that is designed and made by people to be used by people, must be accessible, convenient for everyone in society to use and responsive to evolving human diversity."
} 
To make the information society inclusive and supportive of integration and social cohesion, accessibility must be established as a core value for the array of technologies on which it is based. This is the only way to stop current technologies and future developments from creating barriers to access that mean exclusion and discrimination for persons with disability in terms of their opportunities to participate in society. The success of accessible products depends upon the participation of users with disability in the design phase itself, for their contribution is essential to obtaining quality results and advancements in the design for all strategy.

Designers very often envision a person who meets certain 'standard' parameters of functioning as the end user of their technological products. In reality, no such standard person exists, however-it is a fictitious person conjured from the calculation of statistical averages using many non-standard people. It is crucial, then, that designers adopt the design for all strategy and become aware of the tremendous diversity in modes of functioning and interaction with the technologies found throughout society. Unlike design with standard persons in mind, design for all, as a techno-ethical paradigm, is an approach that, in essence, leads to the integration of human functional diversity.

The realization of technological advances that combine commercial competitiveness with ethics and social cohesion requires that the diverse needs and forms of interaction with technology_-beyond those established, in terms of statistics, by the 'normal' parameters - and with information society environments and devices be respected. Failure to respect functional diversity as a key factor in the design and implementation processes for new technologies will inevitably lead to problems with social participation, as various groups of people suffer discrimination in access to these technologies as well as several information society environments.

We would be putting ourselves, then, in the position of not only respecting the range of functionings common and legitimate to the majority of people, but also taking into account the less common modes of functioning and interaction with technology. Recognition of all the different expressions of functioning that are possible leads to awareness of and respect for functional diversity.

All diversity is expressed in terms of difference. Biological diversity, for instance, is the result of taking into consideration all the different life forms that inhabit an environment. Protecting this diversity would mean attending to the preservation of these life forms. In another sense, protecting, so to speak, the cultural, artistic, ideological and other kinds of diversity in a society would involve ensuring that all possible manifestations within that society may be expressed. It is understood that cultural, artistic, ideological and other types of diversity are of value to society as sources of enrichment.

Functional diversity is inherent to the human being-we all have a singular, characteristic mode of functioning. For the moment, at least, society does not understand that functional diversity is of value. Consequently, society does not see that 
it must be protected, nor does it see the need of ensuring that the variety of possible functionings may be given expression. ${ }^{12}$

Returning to the example of biological diversity, sustaining an environment's diversity means taking into account not only the total number of different life forms it contains but rather their coexistence-that is, the dynamics of interaction among all those life forms. This interaction takes place in the space, territory or common habitat they share. Functional diversity should be viewed as a similar 'coexistence'-a dynamic process of interaction among all the possible alternative expressions of functioning in people in all the spaces and agency environments they have in common. Given that we all express our functioning in a different way, the key concept here is to avoid negativizing or hierarchizing these differences and, instead, view them in a positive and receptive light as a direct manifestation of the functional diversity inherent to the human being.

\section{Conclusions}

We believe that, by incorporating the concept of functional diversity into the functionings space in Amartya Sen's approach, as we have suggested, a capability set of broader spectrum is generated that, as a basis for analyzing well-being and quality of life, serves an equally broader spectrum of society because it is more than just an abstract consideration of the 'standard' person's array of possible functionings. We believe that this enhances the analysis and yields superior sensitivity, given that those 'diverse' functionings - being outside the norm and usually attained with the aid of technological resources-are much more susceptible to being restricted or even invalidated because the design of those technological resources renders them inaccessible, because their cost is too high, or simply because of a lack of such technologies.

In this connection, it is important to highlight Article 4 of the Convention (UN 2006), regarding "General Obligations," where it is established that:

1. States Parties undertake to ensure and promote the full realization of all human rights and fundamental freedoms for all persons with disabilities without discrimination of any kind on the basis of disability. To this end, States Parties undertake: $[\ldots](g)$ To undertake or promote research and development of, and to promote the availability and use of new technologies, including information and communications technologies, mobility aids, devices and assistive technologies, suitable for persons with disabilities, giving priority to technologies at an affordable cost.

A lack of access to technologies makes it impossible for users to appropriate them (Hoyos 2002; Winocur 2007; Echeverría 2008), and this has a dramatic impact on their opportunities for participation in society because it forces their capability set to be

\footnotetext{
${ }^{12}$ It would definitely be appropriate to protect and guarantee such expression, given that any person's current functional abilities will deteriorate over time, and having access to alternative ways of functioning will be of vital importance in those cases.
} 
severely reduced. For those groups of people who are particularly vulnerable to exclusion from the information society, technological developments are like the two sides of a coin: such developments may revolutionize people's lives by giving them the means to enter and interact with the global society, but the other side of it is that these developments can erect barriers that are difficult to surmount if the same basic principles of accessibility are not applied to them. It is a matter of not only analyzing how present-day barriers can be eliminated or how certain technological applications can solve problems for persons with disability but also developing these applications through a prospective and participatory approach aimed at creating inclusive technologies.

On this point, the importance of full participation in the technological design process on the part of users with disability must be emphasized again. The users themselves know best how technological devices can contribute to their greater autonomy, quality of life and level of participation in society, and can assist in evaluating their advantages as well as their drawbacks in the earliest phases of their development.

Remember what has already been stated in the Declaration of Budapest (UNESCO 1999) about the presence and participation of persons with disability in matter of science and technology. In the same regard, the stipulations of Article 8 of the Convention (UN 2006) can be borne in mind:

1. States Parties undertake to adopt immediate, effective and appropriate measures: [...] (b) To combat stereotypes, prejudices and harmful practices relating to persons with disabilities, including those based on sex and age, in all areas of life; (c) To promote awareness of the capabilities and contributions of persons with disabilities.

As the ones most familiar with their own reality, users help to create technological solutions that are more feasible in not only their technical but also their financial and social aspects. User participation also contributes to generating demand for those solutions which, in turn, stimulates their introduction into the market and inspires new lines of research. Similarly, owing to the participation of users - the presence of actors who are generally not taken into consideration in technology development processescitizen groups are better able to generate feasible technological proposals and steer innovation toward the real needs of society (Tewey 1997). ${ }^{13}$

There is another sense in which we believe that incorporating the concept of functional diversity into the functionings space enhances and fine-tunes Amartya Sen's proposed analysis of well-being and quality of life. It is based on the weakness of the concepts of 'standard person' and 'normality'. Any individual could be enjoying his or her assumed classification under these categories until a particular event or process-such as a

\footnotetext{
${ }^{13}$ There is no reason why technological development and innovation should remain solely in the hands of manufacturers and companies' R\&D departments. Moreover, active user participation represents a source of innovation (von Hippel 1988). Some users, especially the so-called 'lead users' (von Hippel 2005), conceive of possible advancements and improvements in the design phase that can be implemented and tested.
} 
temporary injury, a pregnancy, or the reduction in functional abilities that occurs with aging - removes that person from those categories.

Being outside the supposed parameters of normality, even if only temporarily, means becoming different in terms of the functionings that have been affected by the circumstances in each case. Thus, a knee injury will mean that the injured person gets around more slowly, possibly with the aid of crutches, and experiences difficulty with what used to be everyday functionings such as simply going up and down stairs. A pregnant woman faces similar difficulties, as well as a person whose functional ability is gradually deteriorating with age. In all these cases, the individuals will suffer no loss of well-being or quality of life if the social environment available to them is supportive and respectful of functional diversity, whether temporary or permanent.

As we have shown, persons with disability try to get along in societies where established parameters of 'normality' define the acceptable patterns of physical, sensory and psychological functioning (Swain et al. 2004). They also define the rules for participating in the social game where, generally speaking, the possibility of fully including their diverse ways of functioning has not even been contemplated. Elements within the social environment often provoke discrimination against persons with disability, which has forced upon them a struggle to achieve real equality of rights and opportunities and recognition of their functional diversity as a source of enrichment for society (DPI-Europe 2000b).

It is a matter of calling attention to the fact that designing environments, products and services without considering the specific functional needs of persons with disability contributes to discrimination against them (European Commission 2001). Design for all is a means of eliminating barriers. If there is support for its application in all realms of private and community life-home, school, work, leisure, technology and communication, transportation, among others - significant advancement will be possible in eliminating the restrictions that currently hinder persons with disability from participating under equal conditions in the various spaces of life in society.

\section{Acknowledgements}

This article is a result of the research project "Filosofía de las tecnociencias sociales y humanas" (FFI2008-03599) of the Spanish R\&D Plan 2009-2011, and the CSIC Intramural project "Discapacidad, envejecimiento y calidad de vida" (200810I218).

\section{References}

Abberley, P. (1987). The concept of opression and the development of a social theory of disability, Disability, Handicap \& Society 2(1), 5-19.

Aguado, A. (1995). Historia de las deficiencias. Madrid: Escuela Libre Editorial. 
Álvarez, J. F. (2001). Capacidades, libertades y desarrollo: Amartya Kumar Sen. In R. Maíz (comp.) Teorías políticas contemporáneas. Valencia: Tirant lo blanch.

Aslaksen, F., Bergh, S., Bringa, O. and Heggem, E. (1997). Universal Design. Planning and Design for All. The Norwegian State Council on Disability. Web available:

http://home.online.no/ bringa/universal.htm

Barnes, C. (1991). Disabled People in Britain and Discrimination. London: C. Hurst \& Co.

Barnes, C. and Mercer, G. (eds.) (1996). Exploring the Divide. Illnes and Disability. Leeds: The Disability Press.

Barton, L. (ed.) (1996). Disability and Society: Emerging Issues and Insights. London: Longman.

Brisenden, S. (1986). Independent Living and the Medical Model of Disability. Disability, Handicap \& Society 1(2), 173-178.

Cejudo, R. (2007). Capacidad y libertad. Una aproximación a la teoría de Amartya Sen. Revista Internacional de Sociología, Vol. LXV, $\mathrm{n}^{\circ}$ 47, mayo-agosto. Web available: http://revintsociologia.revistas.csic.es/index.php/revintsociologia/article/view/50/50

Cabrera, L. (2009). Nanotechnology: Changing the Disability Paradigm. International Journal of Disability, Community \& Rehabilitation, Volume 8, No. 2. Web available: http://www.ijdcr.ca/VOL08 02/articles/cabrera.shtml

Cadwallader, J. (2007). Suffering difference: normalisation and power. Social Semiotics, 17(3), 375-393.

Castells, M. (1996). La era de la información: Economía, sociedad y cultura. Vol. I: La sociedad red. Madrid: Alianza Editorial.

Centre for Universal Design (CUD) (1997). Principlies of Universal Design. North Carolina State University. Web available:

http://www.design.ncsu.edu/cud/about ud/udprinciplestext.htm

Charlton, J. I. (1998). Nothing about Us without Us. Berkeley: University of California Press.

Clarkson, J., Coleman, R., Keates, S. and Lebbon, C. (eds.) (2003). Inclusive Design. Design for the whole population. London: Springer.

De Asís, R., Bariffi, F. y Palacios, A. (2007). Principios éticos y fundamentos jurídicos. In R. de Lorenzo y L. Cayo Pérez Bueno (Dir.), Tratado sobre Discapacidad. Cizur Menor: Aranzadi.

DeJong, G. (1979). The Movement for Independent Living: Origins, Ideology and 
Implications for Disability Research. East Lansing: Michigan State University Press.

Dobransky, K. and Hargittai, E. (2006). The disability divide in Internet access and use, Information, Communication \& Society, 9(3), 313-334.

DPI-Europe (Disabled People's Internatinonal-Europe) (2000a). Disabled People Speak on the New Genetics. DPI Europe position statement on bioethics and human rights. Web available:

http://freespace.virgin.net/dpi.europe/downloads/bioethics-english.pdf

DPI-Europe (2000b). The Right to Live and be Different. Web available: http://www.johnnypops.demon.co.uk/bioethicsdeclaration/index.htm

Echeverría, J. (2002). Ciencia y Valores. Barcelona: Destino.

- (2006). Ética e ingeniería. Isegoría, no 34, 289-294. Web available:

http://isegoria.revistas.csic.es/index.php/isegoria/article/view/16/16

- (2008). Apropiación social de las tecnologías de la información y la comunicación. Revista Iberoamericana de Ciencia, Tecnología y Sociedad, no 10, vol. 4, 171-182. Web available:

http://oeibolivia.org/files/Volumen\%204\%20-\%20N\%C3\%BAmero\%2010/doss07.pdf

European Commission (1994). Europe's Way to the Information Society. Brussels: European Commission. Web available:

http://www.epractice.eu/en/library/281181

European Commission (2001). Discrimination by Design (Background Paper). Conference, Brussels, $3^{\text {rd }}$ December. Web available:

http://www.accessibletourism.org/resources/dfa_ia_en.pdf

European Institute for Design and Disability (EIDD) (2004). Stockholm Declaration. Web available:

http://www.designforalleurope.org/Design-for-All/EIDD-Documents/Stockholm-

Declaration/

Feenberg, A. (1991). Critical Theory of Technology. New York: Oxford University Press.

- (2002). Transforming Technology. New York: Oxford University Press.

Finkelstein, V. (1980). Attitudes and Disabled People: Issues for Discussion. Nueva York: World Rehabilitation Fund.

G3ict (2007). The Accessibility Imperative. Implications of the Convention on the Rights of Persons with Disabilities for Information and Communication Technologies. Web available:

http://g3ict.org/resource center/g3ict book - the accessibility imperative 
Googin, G. and Newell, Ch. (2003). Digital Disability. United Kingdom: Rowan \& Littlefield

Hamelink, C. J. (2000). The Ethics of Cyberspace. London: Sage.

Hales, G. (ed.) (1996). Beyond Disability. London: Sage.

Hoyos, N. E. (2002). La apropiación social de la ciencia y la tecnología: una urgencia para nuestra región. Interciencia. Revista de Ciencia y Tecnología de América, Vol. 27, $\mathrm{N}^{\mathrm{o}} 2$.

http://redalyc.uaemex.mx/redalyc/pdf/339/33906501.pdf

Laudan, L. (1984). Science and Values. Berkeley: University of California Press.

Lopez Cerezo, J. A., Méndez Sanz, J. A. and Todt, O. (1998). Participación Pública en Política Tecnológica. Problemas y Perspectivas. Arbor, 627, 279-308.

Mace, R., G. Hardie and J. Plaice (1991). Accessible Environments: Toward Universal Design. In W. E. Preiser, J. C. Vischer and E. T. White (Eds.) Design Interventions: Toward a More Human Architecture. New York: Van Nostrand Reinhold.

Martín Gordillo, M. (2005). Cultura científica y participación ciudadana: materiales para la educación CTS. Revista Iberoamericana de Ciencia, Tecnología y Sociedad, $\mathrm{n}^{\circ}$ 6, vol. 2, 123-135. Web available:

http://oeibolivia.org/files/Volumen\%202\%20-\%20N\%C3\%BAmero\%206/doss04.pdf

Mueller, J. L. (1998). Assistive technology and universal design in the workplace. Assistive Technology, 10(1): 37-43.

Oliver, M. (1996). Understanding Disability: From Theory to Practice. London: Macmillan.

Palacios, A. (2008). El modelo social de la discapacidad: orígenes, caracterización y plasmación en la Convención Internacional sobre los Derechos de las Personas con Discapacidad. Madrid: Ediciones Cinca. Web available:

http://www.convenciondiscapacidad.es/Publicaciones/E1\%20modelo\%20social\%20de\% 20discapacidad.pdf

Palacios, A. and Romañach, J. (2006). El modelo de la diversidad. La Bioética y los Derechos Humanos como herramientas para alcanzar la plena dignidad en la diversidad funcional. Madrid: Diversitas. Web available:

http://www.diversocracia.org/docs/Modelo diversidad.pdf

Palacios, A., Romañach, J., Ferreira, M. A. V. and Ferrante, C. (2009). Functional Diversity, Bioethics and Sociological Theory: A New Approach to Disability. Disability \& Society (submitted). 
Pickering, A. (1995). The Mangle of Practice. Chicago: Chicago Univ. Press.

Proctor, R. N. (1991). Value-Free Science? Cambridge: Cambridge Univ. Press.

Putnam, H. (2002). The Collapse of the Dichotomy Fact/Value. Cambridge: Harvard Univ. Press.

Quintanilla, M. A. (1989). Tecnología: un enfoque filosófico. Madrid: Fundesco.

Rescher, N. (1999). Razones y valores en la Era científico-tecnológica. Barcelona: Paidós.

Romañach, J. and Lobato, M. (2005). Functional Diversity. A New Term in the Struggle for Dignity in the Diversity of the Human Being. Web available:

http://www.leeds.ac.uk/disability-

studies/archiveuk/zavier/Functional\%20Diversity\%20\%20\%20\%20\%20\%20\%20\%20\% 20\%20_fv\%20Roma\%F1ach.pdf

Schot, J. (2001). Towards new forms of Participatory Technology Development. Technology Analysis \& Strategic Management, 13(1), 39- 52.

Scotch, R. (1985). Disability as a Basis for a Social Movement: Advocacy and the Politics of Definition. Journal of Social Issues, 44: 159-72.

Seelman, K. D. (2001). Science and Technology Policy. Is Disability a Missing Factor? In G. L. Albrecht, K. D. Seelman and M. Bury (Eds.) Handbook of Disability Studies (pp. 663-692). London: Sage.

Sen, A. (1979). Equality of What? The Tanner Lectures on Human Values. Stanford University, May 22, 1979. Web available:

http://www.tannerlectures.utah.edu/lectures/documents/sen80.pdf

- (1984). Resources, Values and Development. Oxford: Basil Blackwell.

- (1985). Commodities and capabilities. Amsterdam: Elsevier Science.

- (1993). Capability and Well-Being. In M. C. Nussbaum and A. Sen (Eds.) The Quality of Life (pp. 30-53). New York: Oxford University Press.

- (1999). Nuevo examen de la desigualdad. Madrid: Alianza Editorial.

Shakespeare, T. (1994). Cultural Representations of Disabled People: Dustbins for Disavowal? Disability \& Society, Vol. 9, No. 3, 283-299.

Shakespeare, T. and Watson, N. (1996). The body line controversy: a new direction for disability studies? Hull Disability Studies Seminar. Web available:

http://www.leeds.ac.uk/disabilitystudies/archiveuk/Shakespeare/The\%20body\%20line\% 20controversy.pdf 
Shapiro, J. (1994). No Pity. People with Disabilities Forging a New Civil Rights Movement. New York: Times Books. Random House.

Sheldon, A. (2001). Disabled People and Communication Systems

in the Twenty First Century. PhD thesis. Leeds: University of Leeds. Web available:

http://www.leeds.ac.uk/disability-studies/archiveuk/Sheldon/thesis2viv2.pdf

Sheldon, A. (2004). Changing Technology. In Swain, J., French, S., Barnes, C. and Thomas, C. (2004). Disabling barriers-Enabling Enviroments. London: Sage. 155-160.

Stiker, H-J. (1999). A History of Disability. The University of Michigan Press.

Stirling, A., Renn, O., Klinke, A., Rip, A. and Salo, A. (1999). On science and precaution in the management of technological risk. In Technological Risk and Management of Uncertainty, Report ESTO/SPRU.

Swain, J., French, S., Barnes, C. and Thomas, C. (2004). Disabling barriers-Enabling Enviroments. London: Sage.

Tewey, B. (1997). Building Participatory Action Research Partnerships in Disability and Rehabilitation Research. Washington, DC.: U.S. Department of Education, National Institute on Disability and Rehabilitation Research.

Tiles, M. and Oberdiek, H. (1995). Living in a Technological Culture. Human tools and human values. London: Routledge.

UN (2006). Convention on the Rights of Persons with Disabilities. Web available: http://www.un.org/esa/socdev/enable/rights/convtexte.htm

- (2008). Mainstreaming Disability in the Development Agenda. Economic and Social Council Commission for Social Development, E/CN.5/2008/6. Web available:

http://www.un.org/disabilities/default.asp?id=33

UNESCO (1999). Declaration on Science and the Use of Scientific Knowledge. Web available:

http://www.unesco.org/science/wcs/eng/declaration_e.htm

- (2001). COMEST Sub-Commission on "The Ethics of the Information Society". Web available:

http://unesdoc.unesco.org/images/0012/001248/124896e.pdf

Üstün, T. B. et al. (2001). Disability and Culture: Universalism and Diversity. Seattle (WA): Hogrefe \& Huber.

Vacas, F. (2007). TVIC: Tecnologías para la vida cotidiana. Telos, $\mathrm{n}^{\circ} 73$. Web available: http://www.campusred.net/TELOS/editorial.asp?rev=73 
Vanderheiden, G. C. (1998). Universal design and assistive technology in communication and information technologies: alternatives or complements? Assistive Technology, 10(1):29-36.

Von Hippel, E. (1988). The sources of innovation. New York: Oxford Univ. Press.

Von Hippel, E. (2005). Democratizing Innovation. Cambridge, MA: MIT Press.

W3C (2005). How People with Disabilities Use the Web.

http://www.w3.org/WAI/EO/Drafts/PWD-Use-Web/

Winner, L. (2007). Is there a right to shape technology? Argumentos de Razón Técnica, $\mathrm{n}^{\mathrm{o}} 10,305-328$.

Winocur, R. (2007). Nuevas tecnologías y usuarios. La apropiación de las TIC en la vida cotidiana. Telos, $\mathrm{n}^{\circ} 73$. Web available:

http://www.campusred.net/TELOS/articuloexperiencia.asp?idarticulo=1\&rev=73

Wolbring, G. (2003). Disability Rights Approach Toward Bioethics? Journal of Disability Policy Studies, 14 (3), 174-180. 